\title{
Tourism Facilities on Balinese Traditional Housing Extensions in Ubud Village Bali (in Term of Environmental Sustainability)
}

\author{
I Dewa Gede Agung Diasana Putra \\ Department of Architecture Faculty of engeneering, Udayana University, Indonesia \\ Email address of corresponding author: idgadp@yahoo.com
}

\begin{abstract}
Tourism is one of the biggest income generators especially for developing countries. Regarding tourism facilities, most people at tourism areas extend their houses as a home stay, a restaurant, an art shop, salons, and other facilities. Without properly manage, that will have severe impacts upon local communities and environment.

The housing extensions phenomena as tourism facilities and sustainable issue in tourism areas occur at some rural areas in the world including Indonesia and Bali, especially Ubud Village. These house extensions are often designed with adoption of tourism standard, for example, the people tend to adopt the new technology such as using air conditional to anticipate the increase of local temperature (as the effect of climate change). In order to overcome the ecological problem and energy, they use modern building material such as aluminum, plastic, asbestos, etc. That building are often designed by less taking local characteristic of tropical environment. Consequently, the cost was excessively high and the impact on the environment was negative.

The objective of this study is to know how application of Balinese architecture in tourism facilities at Ubud Village. In order to achieve this objective, this research uses stratified random sample survey strategy, and case studies.

The result of research shows that generally the tourism facilities at Ubud Village has been far away use Balinese architecture principle like ventilation, material ornament landscape etc. On the other hand, many facilities use air conditioning and other equipments to find comfortable in the room. That is wasteful of energy and unfriendly to environment. The solutions suggested in this research are the use of sun shading to control of sunlight both vertical and horizontal shading to decrease use of air conditional; the arrangement of the buildings, the attention on environment, the use of material etc.
\end{abstract}

Keywords: extension housing, energy, sustainable

\section{Introduction}

A house is a building for people to live in and to protect them from different kinds of damaging elements such as wind, cold, rain, sun heat and others. Housing means an accommodation in houses. Housing is more than man's way of protecting himself from weather and environment. It is also an expression of his culture and the way of life, of himself, and of family. It is also an indicator of social status and poverty (UNCNS 1992).

In Indonesian society, housing as a shelter reflects the level of living, welfare, safety, personality and culture. Housing can not be seen merely as a living and infrastructure/ facility function, but also as a settlement process and as a facility for people to communicate with the environment (i.e., neighborhood, society, nature surroundings, etc). Therefore, housing is a means for both actualization of the individual and integration with environment (Pembangunan Perumahan, 1994).

Positive implications of housing transformation are housing quality, social economics, housing choices, housing design, etc. It improves housing quality standards like extending of room for main households, decreasing occupancy, improving quality of 
house and improves occupant's satisfaction (Tipple 1992, 1999, 2000; Owusu \& Tipple 1995; Sueca 2003). Furthermore, it is to improve economic aspects too, such as homebased enterprise activity.

In order to provide adequate housing, considerable proportion of people in the developing world transforms their houses. This informal housing supply is also occurring in Bali-Indonesia either in most public housing or in the traditional houses. In the housing transformation, owner-occupiers can gain a considerably more space not just to accommodate their domestic activities but also to generate income, reach a higher social status and improve housing conditions (Sueca N.P 2003).

On the other hand, it also results in negative implications (e.g., growing population, utilities responsibility, sunlight and thermal problems) (Tipple, 1992). Additionally, it also produces inefficient of human and nature resources, lack of labour's knowledge and experience cause inefficient building material (Kellett at all. 1993).

Environment issue is one of problems in housing transformation. Developing countries tend to focus on the relationship between construction and human development, often marginalizing the environmental aspects. Physical environment and construction sectors are linked principally by the demands made later on global nature resources, and this assumes huge environmental significance with the rapid growth in global population and the attendant implications for natural resources. This is especially the case with housing and infrastructure, which are very resource-intensive. Furthermore, insufficient attention to social, environment, cultural and climatic factors in planning and design are one of any characteristic of urban housing in developing countries. (Agenda 21 for Sustainable Construction in Developing Countries 2002).

Community need to adopt and implement an ecological approach to human settlement planning is to ensure explicit embodiment of environmental concerns in planning process and thus promote sustainability. It is one of four actions toward sustainable urban development (Munro, DA, 1991). Thoughtful planning and an integrated approach to design can create buildings that are not only elegant but are also sensitive to their physical setting, economical to build, energy efficient and which will have a long useful life. The fundamental issues that affect the environment both in and around a building which need to be considered in the development toward sustainable are: site planning, orientation, the characteristic of material, building envelope, design of the skin of the building (Stuart Johnson, 1993).

On the other hand, according to ICLEI, "Tourism in natural areas, euphemistically called "eco-tourism," can be a major source of degradation of local ecological, economic and social systems. The intrusion of large numbers of foreigners with high-consumption and high-waste habits into natural areas, or into towns with inadequate waste management infrastructure, can produce changes to those natural areas at a rate that is far greater than imposed by local residents. These tourism-related changes are particularly deleterious when local residents rely on those natural areas for their sustenance. Resulting economic losses can encourage socially deleterious economic activities such as prostitution, crime, and migrant and child labor" (Towards Earth Summit 2002).

Based on the explanation above, sustainable human settlement and sustainable tourism depends on accepting a duty to seek harmony with other people and with nature. The guiding rules are that people must share with each other and care for the earth. The principle of sustainable human settlement and tourism are interrelated and 
mutually supporting. Furthermore, Kirklees (1998) is keen to promote sustainable housing development principles. This principles adopt Agenda 21, which is to improve the quality of life which do not further threaten our fragile planet. It is a plan for sustainable development in the $21^{\text {st }}$ Century. The principles are: Energy Efficiency; Green Product Guide; Recycling; Biodiversity Issues; Occupants Requirements; Scheme Development Standards and Lifetime Homes; Safety and Health and Secured by Design.

As a part of Human Settlement, traditional architecture especially the traditional housing in hot humid conditions is an environmentally friendly house that is utilizing optimally the potential of local natural. Thus it will be longed for both a thrifty and economical house, even cheap on its development process and a thrifty energy on its operation as well. As we know, it is essentially categorized as the eco-house seen intern of: its integrity on environment, the arrangement of the buildings unit, the use of land, the attention on environment, the use of material, natural energy and the other natural resources as well.

Many tourism destinations are traditional villages in many developing countries. They include Indonesia in particular Bali, which has experienced the most dramatic changes. As famous traditional village and tourism area, they have a rapid population and economic growth. Rapid tourists' growth leads to an increase in demand of tourism facilities as one of basic needs at tourism destination, which is to adopt Traditional Architecture. The number of new tourist facilities has increased annually. In fact, towards the end of the last decade, almost every year, a new tourist's facilities building are constructed.

Tourism is now considered as having the potential for bringing considerable economic and social benefit to tourism areas through income enhancement and infrastructure upgrading, particularly for marginal and less economically developed regions. But while rural tourism and recreation industries support economic and social restructuring, they tend to be most successful in rural economies that are already healthy (Roberts \& Hall, 2001).

According Key Themes and Issues report (2005), 99\% of all tourism-related establishments in rural areas in the USA qualify as small businesses); in New Zealand, the tourism industry is estimated to consist of between 13,500 and 18,000 SMEs; and. in Israel, almost all rural tourism businesses are classified as small and family based, with $95 \%$ of those in the accommodation sector employing less than three people.

These phenomena occur at other tourism area in the world including Indonesia. In Bali, one of the famous tourism destinations in Indonesia, people extend their traditional house to be tourism facilities such as a home stay, a restaurant, a travel agent office, an art shop, and so on. These house extensions are often designed without taking the ecological aspects as traditional architecture. As the tourism standard, people tend to adopt the new technology in order to overcome the ecological problem which is not adapted to the local characteristic of tropical environment. Consequently, the cost was excessively high and the impact on the environment was negative. These are not sustainable development and tourism.

From the explanation above, the relation between house extensions, sustainable development and sustainable tourism area is clear. Furthermore, based on the research above, this relation has not addressed by other researchers. The problem of relation between the continuity of building processes, sustainable development and built form is of great significance to sustainability of traditional housing toward sustainable tourism 
area. This relation affects the environment in the long term; Therefore, it is vital to integrate them.

\section{Materials and Method}

\subsection{Theoritical Framework}

One principles of the Balinese cosmos is the mountain ward (kaja)/ seaward (kelod) opposition. The use of this kind of expression for denoting direction is usual in the Indonesian archipelago. In Bali at least, to this geographical orientation is added the religious connotation of purity / pollution. The word kaja is used with connotation sacred direction while the word kelod has the opposite meaning. This kaja/kelod orientation matches a Hindu teaching called Tri Hita Karana, which is widely accepted in Bali. It says that the world is composed or three parts: the relationship with god, relationship with human beings and relationship with environment.

The principle of tripartite division penetrates the arrangement of building in villages and house yards. Those which have sacred character should be located mountain ward while those which exhaust dirty or polluted things such garbage and excrement are placed seaward.

The same principle is also applied to the human body, which is considered as micro cosmos (bhuana alit), compared to the universe as macro cosmos (bhuana agung). One of the most important teaching of Hindu Balinese religion stresses the harmony between the micro and the micro cosmos. The human body is divided again into three parts, which is the head (utama angga), the body (madya angga) and the feet (nista angga). In the same way, a Balinese traditional building such as a house, has the three parts composition, namely the roof as the head, pillars as the body and a foundation as the feet.

Balinese traditional architecture user several kinds of measuring unit, the lengths of which are taken from various parts of the human body. Furthermore, the lontar documents say that when a domestic house is to be constructed the measurements of its owner's body should be used for planning it, so that the harmony between the house and the family who dwell in it might be complete.

The distance between the tips of the middle fingers when the arms are stretched out as far as they will reach, is called depa, the distance from the elbow to the tip of the out stretched middle finger is called hasta. The combination of these two distances, namely one depa plus one hasta, is called depa agung. One more measuring unit of this group is the width of the fist with thumb outstretched, called musti .

The length of the feet, called tapak, and the width, called tapak ngandang, are used to measure the distance between in a yard. When the yard is rather narrow, another unit called cengkang, the distance between the tip of the stretched forefinger and thumb, could be used in placed or the tapak.

To arrange buildings harmoniously in a yard, the measurement tapak is used for deciding the distance between them. To know the proper and improper distances, the lontar documents indicate another counting system: Sri--Indra--Guru--Yama--Rudra-Brahma--Kala -- Uma. All these are the names of god and show the character of each distance. 

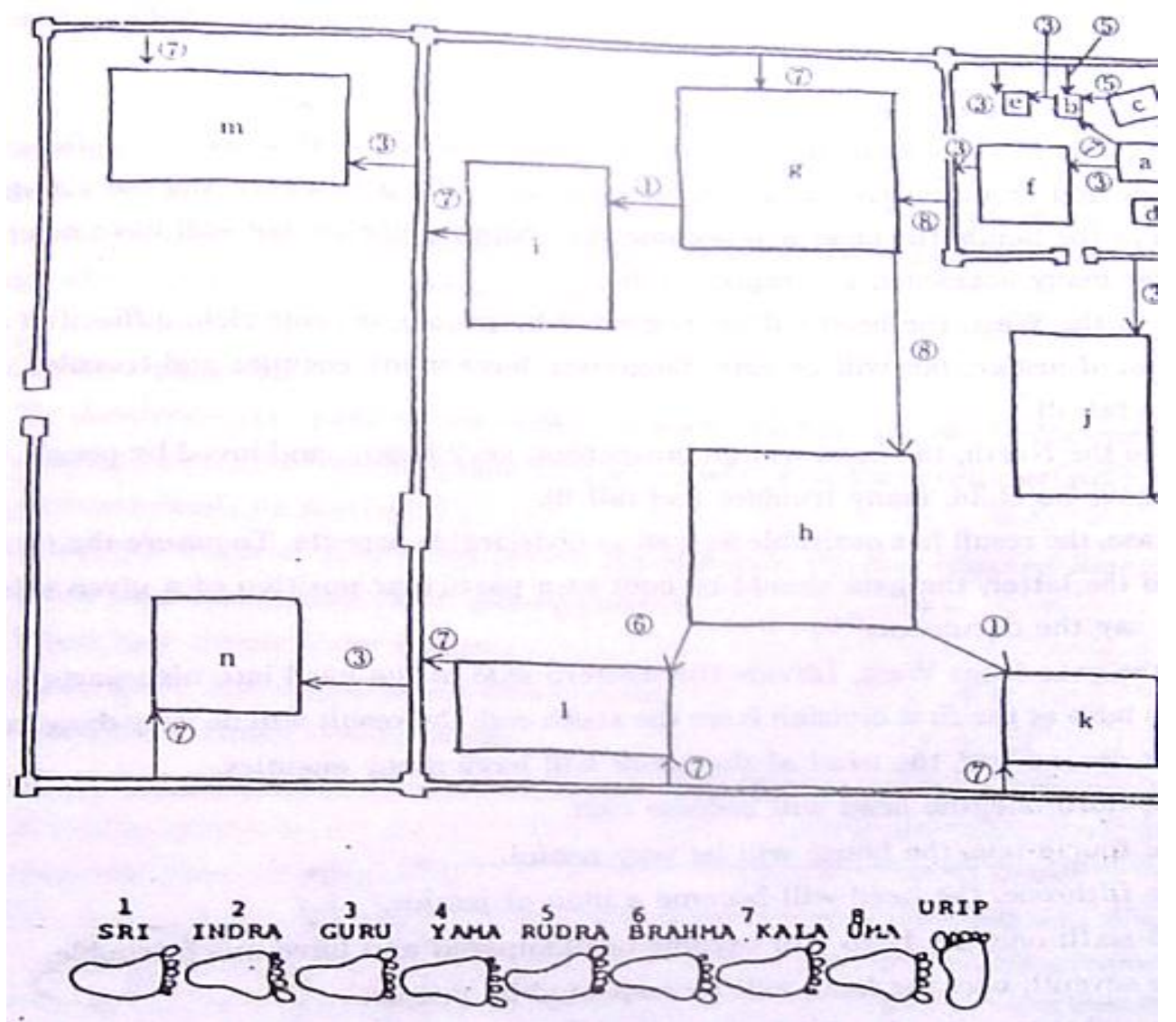
a. Kemulan
b. Taksu
i. Bale Tiang Sanga
c. Padmasari
j. Bate Mundak
d. Pengelurah
k. Jinens
e. Tunggun Karang
f. Piyasan
1. Paon
k. Bale Bandung
m. Bale Gonk
n. Bale Bungun
h. Bale Murda

Figure 1: Arrangement of Building in the Balinese House yard. Source: Haruya Kagami, 1988,

Balinese traditional buildings are made of wood, brick, and stone. Some are pavilion style, having a wooden body thatched with tall grass (alang-alang) and a foundation platform of piled up soil and laid brick. 


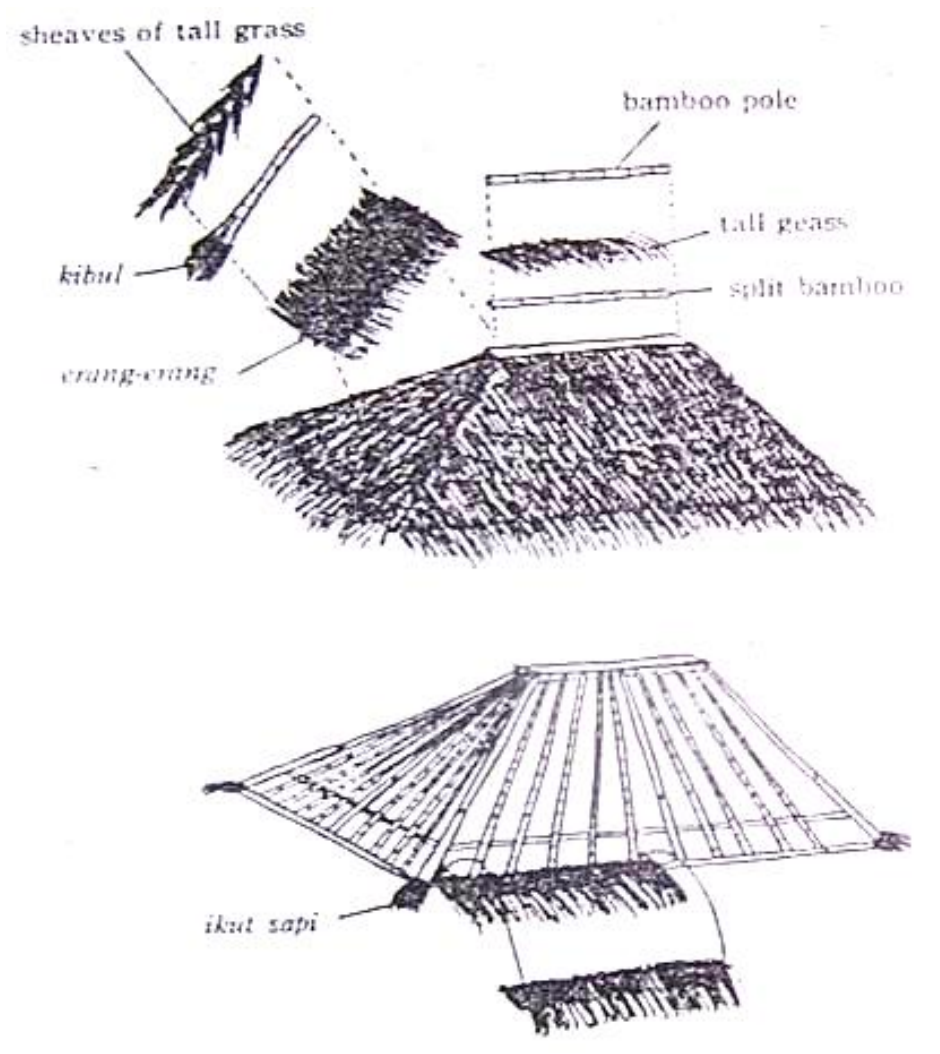

Figure 2: One of Kinds Roofing Process Source: Haruya Kagami, 1988,

\subsection{Methodology}

A methodology and research method which is used in this study consists of:

a. Reviewing tourist's facilities in ubud village. This was conducted through selecting theory about eco house, Balinese architecture, and concept of thrifty energy in design architecture.

b. Data collection and interviews have been held with representatives of the government, and private sector who relate to the tourist's facilities to get information about conditions of tourist's facilities.

c. A qualitative analysis will be considered as the quantity of data collected and time consume are only limited and much data are in the form of case studies. The approach is based on qualitative data and information from the representative people.

\section{Results and Discussion}

The aplication of balinese architecture as eco house in tourism fasilities has occurred both Gianyar, Badung and several other parts of Bali province. Ubud is a village at Gianyar regency is aplicated too.

The utilization of Balinese architecture in fasilities of tourism ranges from merely decorative features up to complete site plan arrangements. Typical balinese house is an compound with open -courtyard that comprise of several building called bale, enclosed by wall. Rules of spatial organization according to cosmological orientation apply to everyone. Bale is an open air building that exemplify Balinese traditional architecture 
concept of truth in construction. Several tourism facilities especially villa or bungalow and cottages use this concepts. Several building with swimming pool in open courtyard is constructed to give costumer a comfortable. Several hotel developments utilize the village pattern, and some of these developments also include the utilization of wall enclosures for their individual units, almost exactly like in Balinese house. Its individual units include several structures and lots of openness, within the enclosed wall that allows maximum privacy for the user.

The other hand, the peoples of Ubud Village, opens their house for tourist residences along holiday in Ubud. The kinds of this tourist's residences called home stay. Typical of Home stay is an compound with open - courtyard that comprise of several building, like house of Balinese people. Previously, Home stay and other residences don't use air conditioning to comfortable costumers. The building uses cross ventilation to create thermal comfort. The distance between buildings has modern measure like meters, they don't use traditional measure like tapak, depa, hasta ext. But they have enough distance between buildings to create thermal comfort. They are functioned as landscape.

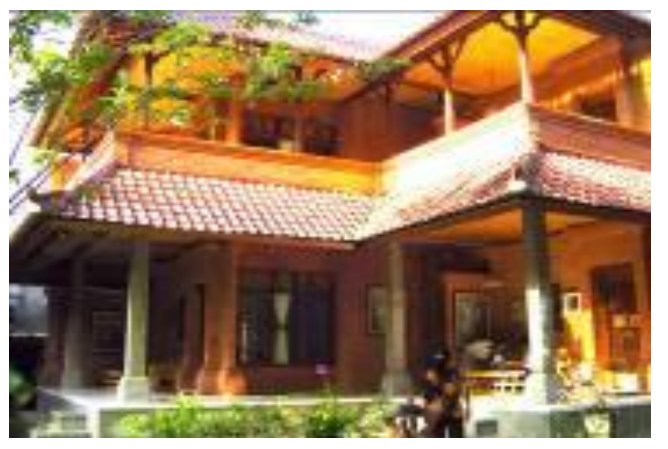

Photo 1: Tourist Facilities at Ubud Village
Table 1: Inter Building Distance

\begin{tabular}{|l|r|}
\hline \multicolumn{2}{|c|}{ Inter Building Distance } \\
\hline \multicolumn{1}{|c|}{ metre } & \multicolumn{1}{c|}{$\%$} \\
\hline$<0,5$ & 30,00 \\
\hline $0,5-1$ & 60,00 \\
\hline $1,0-2,0$ & 6,67 \\
\hline $2,0-5$ & 3,33 \\
\hline$>5$ & \multicolumn{2}{|c|}{ Source: Diasana Putra, 2010 }
\end{tabular}

The material for building use traditional material like brick and stone for the body, but for roof, several building use roof tile and little bit use long grass. Almost all of building use ceramic for floor.

But now, every time, tourist visit ubud village rapid growth, make rapid density of tourist facilities. After that, people construct building at opens area near building before. It's cause, the distance most closed between buildings. This condition, cause the building can't make thermal comfort just use cross ventilation. In fact now, several building uses air conditioning. This condition is wastes energy.

To get thermal comfort, tourist facilities must adopt Balinese traditional architecture concepts like measure, distance, material, ventilation concepts, landscape and other philosophy concepts.

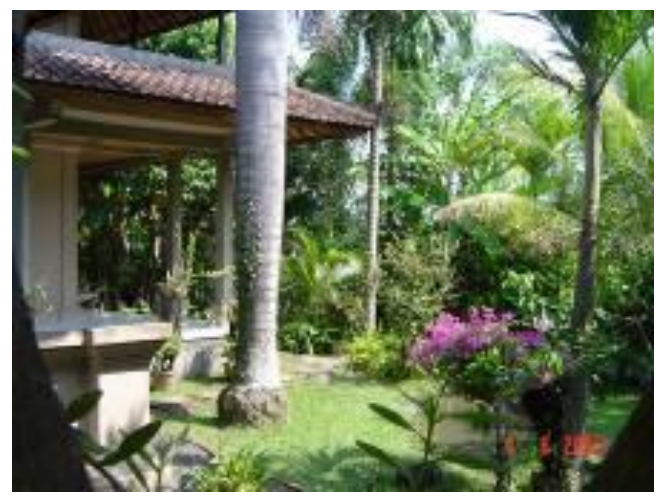

Photo 2: Landscape at Indraprasta 2

Bungalow for thermal comfort 
Table 2: Building Material

\begin{tabular}{|c|c|c|c|c|c|c|c|}
\hline \multicolumn{7}{|c|}{ Building Material } \\
\hline Wall & procentage & structure & procentage & $\begin{array}{c}\text { Roof } \\
\text { structure }\end{array}$ & procentage & Roof & procentage \\
\hline bric & $80 \%$ & concrete & $100 \%$ & wood & $96 \%$ & Roof tile & $93 \%$ \\
\hline stone & $20 \%$ & & & bambo & $4 \%$ & reed & $7 \%$ \\
\hline
\end{tabular}

Source: Diasana Putra, 2010

Table 3: Interior Material

\begin{tabular}{|c|c|c|c|c|c|c|c|}
\hline \multicolumn{2}{|c|}{} & & \multicolumn{7}{c|}{ Interior Material } \\
\cline { 2 - 8 } floor & wall & $\begin{array}{c}\text { without } \\
\text { ceiling }\end{array}$ & bambo plait & Gips um & Playwood & rattan & concrete \\
\hline ceramics & plaster & & & & & & $0 \%$ \\
\hline $100 \%$ & $100 \%$ & $3.3 \%$ & $73.3 \%$ & $3.3 \%$ & $16.8 \%$ & $3.3 \%$ & \\
\hline
\end{tabular}

\section{Conclusion}

Although tourist facilities do not use all of rules Balinese traditional architecture, several tourism facilities especially home stays, villas or bungalows and cottages use Balinese architecture concepts like several building with courtyard, material or concept of cross ventilation. Courtyard is used as landscape to create thermal comfort around the building.

\section{References}

Bidja I Md, 2000, Asta Kosala-Kosali, Asta Bumi, Denpasar: Penerbit BP

Diasana Putra, 2010, Sustainabililty of Traditional Housing extentions as Tourism Facilitis in Ubud Village, in Procedings of International Conference on Sustainable Tevhnology Development, Denpasar

Eko Budiharjo \& Djoko Sujarto, 1999, Kota Berkelanjutan, Penerbit Alumni, Bandung.

Hayuma Kagami, 1988, Balinese Traditional Architecture in Process, Inuyama: the Litle World Museum of Man.

Heinz Frick \& Tri Hesti Mulyani, 2006, Arsitektur Ekologis, Penerbit Kanisius dan Soegijapranata Univesity Press,Yogyakarta.

Ken Yeang, 1994, Bioclimatic Skyscrapers, London, Artemis London Limited.

Lester R. Brown (1981), Building a Sustainable Society, London: W.W. Norton and Company.

Munro. DA (1991), Caring for the Earth: A Strategy for Sustainable Living, Switzerland: IUCN, UNEP, WWF.

Roy, Manoj (2009) Planning for sustainable urbanisation in fast growing cities: Mitigation and adaptation issues addressed in Dhaka, Bangladesh, Habitat International $33: 276-286$

Sarah and Thompson-Fawcett, Michelle (2008), The Social Sustainability of Medium Density Housing: A Conceptual Model and Christchurch Case Study',Housing Studies, 23:3,423 - 442

Sulistyawati, 1999, Design Guidelines of an Old Traditional Village in Anticipating Tourism Impacts, in Procedings of Seminar on Vernakular Settlement, Jakarta: The Faculty of Engineering University of Indonesia.

Teguh Utomo Atmoko, 1999, Balinese Architecture in Property Development, in Procedings of Seminar on Vernakular Settlement, Jakarta: The faculty of Engineering University of Indonesia.

Vaughn Bradshaw, 1985, Building Control systems, John Wiley \& Sons, New York 